\title{
Studies on Measurements of the Scalp Tissue of the Japanese Adult (I)
}

\author{
By \\ Yutaka Yonemoto \\ Department of Anatomy Gifu University \\ Medical School, Gifu, Japan \\ (Director: Professor Takao Setoguti)
}

\section{Introduction}

Although many studies have been made in which measurements were taken of scalp tissue of man, most reports, except for measurements taken on the living body, deal with one part of the tissue or include only a small number of cases and comprehensive studies based upon histological sections from a large number of cases are few. In particular, there are no such studies for the Japanese. The present work was begun to obtain accurate information on the interrelation of the head hair with other structures of the head skin and on the changes that occur with age.

\section{Material and method}

The material consisted of the skin of the vertex which had been taken with abundant subcutaneous connective tissue from cadavers of 30 Japanese of both sexes (male 16, female 14), ages 28 to 90 . After cutting these pieces of tissue into sections of $10 \mathrm{~mm} \times 10 \mathrm{~mm}$ and $5 \mathrm{~mm} \times 15 \mathrm{~mm}$, they were fixed in $10 \%$ formalin solution and embedded in celloidin-paraffin. The $10 \mathrm{~mm} \times 10 \mathrm{~mm}$ sections were used to prepare $20 \mu$ transverse serial sections while the $5 \mathrm{~mm} \times 15 \mathrm{~mm}$ sections were used for $20 \mu$ vertical serial sections. Hematoxylineosin double staining was done.

\section{Results and discussion}

\section{The skin}

Measurement of the thickness of skin was obtained by selecting the thickest portion of each vertical section showing no artificial 
Table 1. The thickness of the skin of the vertex. $(\mu)$

\begin{tabular}{|c|c|c|c|}
\hline age & $\begin{array}{c}\text { The } \\
\text { thickness } \\
\text { of } \\
\text { epidermis } \\
(\mu)\end{array}$ & $\begin{array}{c}\text { The } \\
\text { thickness } \\
\text { of } \\
\text { dermis } \\
(\mu)\end{array}$ & $\begin{array}{l}\text { The } \\
\text { thickness } \\
\text { of skin } \\
(\mu)\end{array}$ \\
\hline \$ 28 & 78 & 1681 & 1759 \\
\hline 우31 & 30 & 1457 & 1487 \\
\hline 우 31 & 80 & 1528 & 1608 \\
\hline 今 32 & 92 & 1661 & 1753 \\
\hline 今36 & 66 & 1666 & 1732 \\
\hline average & 69 & 1599 & 1667 \\
\hline 우 40 & 78 & 818 & 896 \\
\hline$\delta 41$ & 88 & 2208 & 2296 \\
\hline 今 44 & 51 & 1575 & 1626 \\
\hline$\widehat{o} 47$ & 82 & 1812 & 1894 \\
\hline average & 74 & 1603 & 1678 \\
\hline 우 58 & 66 & 1434 & 1500 \\
\hline$\$ 58$ & 52 & 1850 & 1902 \\
\hline average & 59 & 1642 & 1701 \\
\hline 우 60 & 38 & 1315 & 1353 \\
\hline 今 64 & 67 & 992 & 1059 \\
\hline$\widehat{\delta} 65$ & 94 & 681 & 775 \\
\hline 우66 & 76 & 933 & 1009 \\
\hline 우 67 & 43 & 1138 & 1181 \\
\hline 今 67 & 33 & 683 & 716 \\
\hline 669 & 69 & 1480 & 1545 \\
\hline average & 60 & 1031 & 1091 \\
\hline$\$ 70$ & 83 & 1761 & 1844 \\
\hline$\$ 70$ & 54 & 903 & 957 \\
\hline 우71 & 70 & 726 & 796 \\
\hline 오72 & 65 & 947 & 1012 \\
\hline 우74 & 65 & 745 & 810 \\
\hline 우76 & 50 & 1101 & 1151 \\
\hline average & 64 & 1030 & 1095 \\
\hline 우 80 & 38 & 1270 & 1308 \\
\hline 우 82 & 49 & 483 & 532 \\
\hline 우 82 & 44 & 742 & 786 \\
\hline 今 82 & 54 & 1182 & 1236 \\
\hline 우 83 & 39 & 1364 & 1403 \\
\hline o 90 & 70 & 942 & 1012 \\
\hline average & 49 & 997 & 1046 \\
\hline
\end{tabular}

separation of the stratum corneum. The thicknesses of the stratum germinativum and dermis were measured with a micrometer and then the mean was calculated.

\section{a) Epidermis}

As shown in Table 1 , the average of all measurements on 30 cases of both sexes, aged 28 to 90 years, was $62 \mu$. The individual measurements ranged from a maximum of $94 \mu$ (65-year-old male) to a minimum of $30 \mu$ (31-year-old female), showing marked individual differences.

Cases were classified by age for comparison purposes as follows: 5 cases from age 28 (male) to 36 (male) in the 30 year age group; 4 cases from age 40 (female) to 47 (male) in the 40-year age group; 2 cases of age 58 (female) and 58 (male) in the 50-year age group; 7 cases from age 60 (female) to 69 (female) in the 60-year age group ; 6 cases from age 70 (male) to 76 (female) in the 70-year age group; and 6 cases from age 80 (female) to 90 (male) in the 80 -year age group. The average value for each group is as follows: $69 \mu$ for the 30 year age group; $74 \mu$ for the 40 -year age group ; $59 \mu$ for the 50 -year age group ; $60 \mu$ for the 60 -year age group ; $64 \mu$ for the 70-year age group; and $49 \mu$ for the 80 -year 
age group. Although no definite age tendency can be seen among the groups, the 80 -year age group excluding the 1 case age 90 (male) showed a considerable decrease in thickness of the epidermis (Fig. 1).

When examined by sex, the average for males was $68 \mu$ and that for females was $56 \mu$, being slightly thicker in males.

The thickness of the skin of the vertex has been measured on living individuals ( $\mathrm{T}$ od d and $\mathrm{K}$ ue $\mathrm{nzel}$ 1924, and $\mathrm{P}$ a r s o n 1928) and by X-ray ( $\mathrm{Y}$ o u $\mathrm{n} \mathrm{g}$ 1959), but otherwise inspection of histological sections has been done by Birkner (1906), Y a z a w (1933), $\mathrm{L}$ ig h t (1949), K od a m a (1961) and G i a c o m etti (1965).

In the study of Japanese by $\mathrm{K}$ od a m a (1961), who examined 54 cases, values of $77 \mu$ for the 30-year age group, $60 \mu$ for the 40-year age group, $63 \mu$ for the 50-year age group, $62 \mu$ for the 60-year age group, $54 \mu$ for the 70-year age group, and $54 \mu$ for the 80 -year age group have been reported. Y a a w a (1933) has measured 5 cases including children and the Table 2. Gia cometti's report (1965). values obtained for his 3 adult

\begin{tabular}{|l|c|c|}
\hline \multicolumn{1}{|c|}{ Age group } & Epidermis $(\mu)$ & Skin $(\mathrm{mm})$ \\
\hline New-born & 33 & 2.4 \\
Infant & & \\
$\quad$ (3 mth-1 yr) & 33 & 3.2 \\
Adult & & \\
$\quad 20-30 \mathrm{yr}$ & 40 & 5.2 \\
$30-50 \mathrm{yr}$ & 47 & 5.4 \\
$50-70 \mathrm{yr}$ & 37 & 4.8 \\
$70-80 \mathrm{yr}$ & 35 & 4.7 \\
$80-90 \mathrm{yr}$ & 35 & \\
\hline
\end{tabular}
cases were $63 \mu$ in a 22-year-old female, $63 \mu$ in a 28-year-old male and $63 \mu$ in a 35-year-old female. Thus, the average value of $62 \mu$ in my examination is slightly less than that of $\mathrm{Yazaw}$ a or $\mathrm{Ko}$ $\mathrm{d}$ a $\mathrm{ma}$. In the description of 6 cases of Chinese by B ir kner, an average of $60.4 \mu$ is given for the skin of the vertex which is approximately the same as my total average. Giacometti examined the epidermis of 62 cases ranging from fetus to age 90 years and found an average of $39 \mu$ for adults (Table 2). His values are generally lower than mine because I had measured the thickest portion, but his finding of the highest value in the 30 to 50 -year age groups is in agreement with my results. Evans et al. (1943) measured the epidermis obtained by biopsy from the antecubital region of white males and found that although contraction due to fixation is greater in young individuals (20 and 30-year age groups) than in the older group (over age 80), the average value for the aged was $65 \mu$ which is still less than in the younger age groups. Berres (1957) measured the thickness of the epidermis of the abdomen in the group under age 20 and noted that the thickness gradually de- 
caeases with aging. Thus, the epidermis in all regions presumably is the greatest between the 20 to 40 -year age groups and tends to decrease rapidly after age 80 (Fig. 1).

b) Dermis

As shown in Table 1, measurements were taken on the same 30 cases for which the epidermis was measured. The total average was $1316 \mu$. The maximum was $2208 \mu$ in a 41 -year-old male and the least was $483 \mu$ in a 82 -year-old female. The average for each age group was as follows: $1599 \mu$ in the 30-year age group; $1603 \mu$ in the 40 -year age group; $1642 \mu$ in the 50 -year age group; $1031 \mu$ in the 60-year age group; $1030 \mu$ in the 70 -year age group; and $997 \mu$ in the 80-year age group. Thus, there is a marked decrease in thickness of the dermis beyond age 60. However, there were considerable individual variations among cases in each age group; a value of $818 \mu$ was noted in a 40-year-old female and a value of $1102 \mu$ in a 57-year-old male which are especially thin for the corresponding age groups while a value of $1480 \mu$ was noted in a 69year-old female and a value of $1761 \mu$ was noted in a 70-year-old male which are particularly thick for those age groups. By sex, the average for males was $1399 \mu$ and for females $1096 \mu$, being consisderably thicker in males.

The average value for the dermis obtained by $\mathrm{Yazawa}$ is $1344 \mu$ while may value for the dermis of the vertex for cases of the same age group is $1598 \mu$. In my observations, the thickness of the dermis of the vertex decreased beyond age 60 . Berres (1957) likewise has noted the thickness of the dermis of the abdomen to decrease with aging.

c) Thickness of skin

The thickness of skin was obtained by adding the values for the epidermis and dermis. An average of $1379 \mu$ was obtained. As shown in Table 1, the maximum was $2296 \mu$ (41-year-old male) and the minimum was $532 \mu$ (82-year-old female).

The average value for each age group was as follows: $1667 \mu$ for the 30-year age group; $1678 \mu$ for the 40-year age graup; $1701 \mu$ for the 50-year age group, $1091 \mu$ for the 60-year age group; $1095 \mu$ for the 70-year age group; and $1046 \mu$ for the 80 -year age group. Thus, there is an obvious decrease after age 60 (Fig. 1) which is due to the decrease in thickness of the dermis. Further, the average value for males was $1467 \mu$ and that for females was $1152 \mu$.

Y a z a w a (1933) has reported a value of $1410 \mu$ for the skin which is lower than the measurements of mine for a comparable 


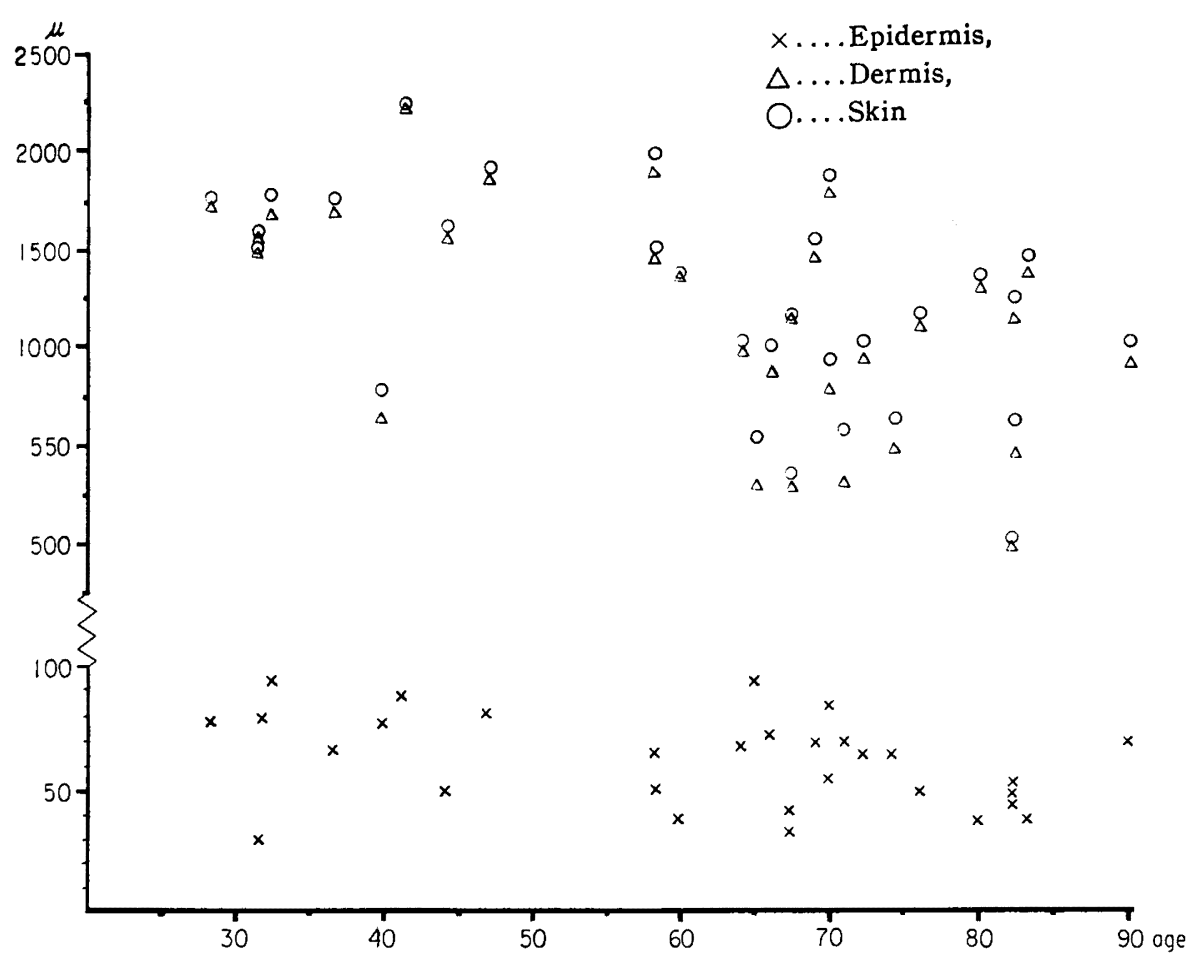

Fig. 1. The scatter gram showing relationship among individual measurements of epidermis, dermis, and skin.

30 year age group. Light (1949) measured the skin and subcutaneous fat layer of the scalp in 28 cases of varying ages. Sc h u$\mathrm{m} \mathrm{a} \mathrm{cher} \mathrm{(1931)} \mathrm{has} \mathrm{reported} \mathrm{that} \mathrm{of} \mathrm{the} \mathrm{whole} \mathrm{body} \mathrm{the} \mathrm{thickness}$ of the skin is thickest on the back, nates, flexor side of hands and feet, and the scalp but that there is no relation between the thickness of the epidermis and dermis. Neither has the present author found any relation between the epidermis and dermis.

\section{The hair}

In determining the number of hair follicles, number of hairs and the diameter of hair, horizontal serial sections through the level of hair follicles were compared with 15 photographic enlargements of the same sections in order to avoid errors due to duplication. The number of hair follicles and number of hairs per square centimeter was counted on the sections. The diameter of hair was measured with a micrometer on the horizontal serial sections through 
Table 3. The number of hair-follicles and hairs, and the hair diameter.

\begin{tabular}{|c|c|c|c|c|c|c|}
\hline age & $\begin{array}{c}\text { The } \\
\text { number } \\
\text { of } \\
\text { hair-follicles }\end{array}$ & $\begin{array}{l}\text { The } \\
\text { number } \\
\text { of all } \\
\text { hairs }\end{array}$ & $\begin{array}{l}\text { The number } \\
\text { of hairs } \\
\text { except for } \\
\text { hairs less } \\
\text { than } 30 \mu \\
\text { in diameter }\end{array}$ & $\begin{array}{c}\text { The } \\
\text { number of } \\
\text { hairs less } \\
\text { than } 30 \mu \\
\text { in } \\
\text { diameter }\end{array}$ & \begin{tabular}{|} 
The diameter \\
of hairs \\
except for \\
hairs less \\
than $30 \mu$ \\
in diameter
\end{tabular} & $\begin{array}{l}\text { The } \\
\text { diameter } \\
\text { of all } \\
\text { hairs }\end{array}$ \\
\hline 今 28 & 265 & 208 & 177 & 31 & 90 & 60 \\
\hline 우 31 & 227 & 205 & 169 & 36 & 75 & 60 \\
\hline 우 31 & 396 & 329 & 280 & 49 & 110 & 86 \\
\hline § 32 & 364 & 307 & 208 & 99 & 87 & 59 \\
\hline 今 36 & 273 & 254 & 196 & 58 & 84 & 71 \\
\hline average & 305 & 261 & 206 & 55 & 89 & 67 \\
\hline 우 40 & 460 & 410 & 343 & 67 & 67 & 58 \\
\hline 今 41 & 357 & 294 & 161 & 133 & 59 & 41 \\
\hline 今 44 & 342 & 325 & 285 & 40 & 83 & 71 \\
\hline 今 47 & 258 & 236 & 182 & 54 & 85 & 67 \\
\hline average & 354 & 316 & 242 & 74 & 74 & 59 \\
\hline 우 58 & 258 & 217 & 193 & 24 & 71 & 57 \\
\hline 今 58 & 318 & 244 & 205 & 39 & 63 & 47 \\
\hline average & 288 & 230 & 199 & 31 & 67 & 52 \\
\hline 우 60 & 96 & 0 & 0 & 0 & 0 & 0 \\
\hline 今 64 & 294 & 159 & 99 & 60 & 60 & 36 \\
\hline ๙ิ 56 & 298 & 163 & 68 & 95 & 43 & 31 \\
\hline 우 66 & 186 & 121 & 116 & 5 & 66 & 51 \\
\hline 우 67 & 311 & 166 & 81 & 85 & 61 & 30 \\
\hline 今 67 & 241 & 120 & 116 & 4 & 64 & 46 \\
\hline 우 69 & 266 & 220 & 215 & 5 & 59 & 52 \\
\hline average & 243 & 136 & 99 & 36 & 50 & 35 \\
\hline 今 70 & 142 & 127 & 0 & 127 & 0 & 16 \\
\hline 今 70 & 181 & 130 & 60 & 70 & 43 & 28 \\
\hline 오 71 & 74 & 0 & 0 & 0 & 0 & 0 \\
\hline 우 72 & 209 & 115 & 110 & 5 & 68 & 45 \\
\hline 우 74 & 159 & 118 & 110 & 8 & 63 & 44 \\
\hline 오 76 & $\cdot 15$ & 0 & 0 & 0 & 0 & 0 \\
\hline average & 130 & 82 & 47 & 35 & 29 & 22 \\
\hline 우 80 & 14 & 0 & 0 & 0 & 0 & 0 \\
\hline 우 82 & 71 & 51 & 50 & 1 & 59 & 59 \\
\hline 우 82 & 287 & 0 & 0 & 0 & 0 & 0 \\
\hline 今 82 & 144 & 76 & 43 & 33 & 47 & 34 \\
\hline 우 83 & 152 & 126 & 117 & 9 & 48 & 44 \\
\hline 今 90 & 215 & 57 & 17 & 40 & 39 & 27 \\
\hline average & 147 & 52 & 38 & 14 & 32 & 27 \\
\hline
\end{tabular}


the level of the hair follicle. For oval shaped hair, the long and short diameters were added and divided by two to obtain the diameter of the hair.

a) Number of hair follicles and hairs

The total average number per square centimeter for the 30 Japanese adults that I examined was 229 hair follicles and 159 hairs. Of all cases examined, as shown in Table 3, the number of hair follicles ranged from a maximum of 396 (31-year-old female) to a minimum of 14 (80-year-old female) while the number of hairs ranged from a maximum of 329 (31-year-old female) to a minimum of complete absence in 5 cases (60-year-old female, 70-year-old female, 76 year-old female, 80-year-old female, 82-year-old female). The average number for each age group was as follows: Number of hair follicles was 305 for the 30-year age group; 354 for the 40-year age group; 288 for the 50-year age group; 243 for the 60-year age group; 130 for the 70-year age group; and 147 for the 80 -year age group. The number of hairs was 261 for the 30-year age group; 316 for the 40-year age group; 231 for the 50-year age group; 136 for the 60year age group; 82 for the 70-year age group; and 52 for the 80 year age group.

No definite change with age was seen among the 30 to 50 -year age groups. Beyond age 60, however, a marked reduction in the number of both hair follicles and hairs is seen with age (Fig. 2); reduction of number of hairs preceeds that of hair follicles and in particular there are cases in which hair is completely absent although there are hair follicles.

As shown in Table 3, measurement has also been made of the number per square centimeter of small hairs of about the same size of lanugo type hair, less than $30 \mu$ in diameter, which cannot be determined by gross inspection. There were large individual differences in the frequency of hairs of this type. The maximum number noted was 133 in a 41-year-old individual, and there even was a case in which the size of all hairs noted was $30 \mu$ or less ( 70 -year-old male). The average number of such hairs in each age group is as follows: 55 for the 30-year age group; 74 for the 40-year age group; 31 for the 50-year age group; 36 for the 60-year age group; 35 for the 70 year age group; and 14 for the 80 -year age group. Thus, there apparently is no relation between the number of hairs that are $30 \mu$ or less and age (Fig. 2).

To determine the proportion of hair follicles having hair, the number of hairs was divided by the number of hair follicles to ob- 


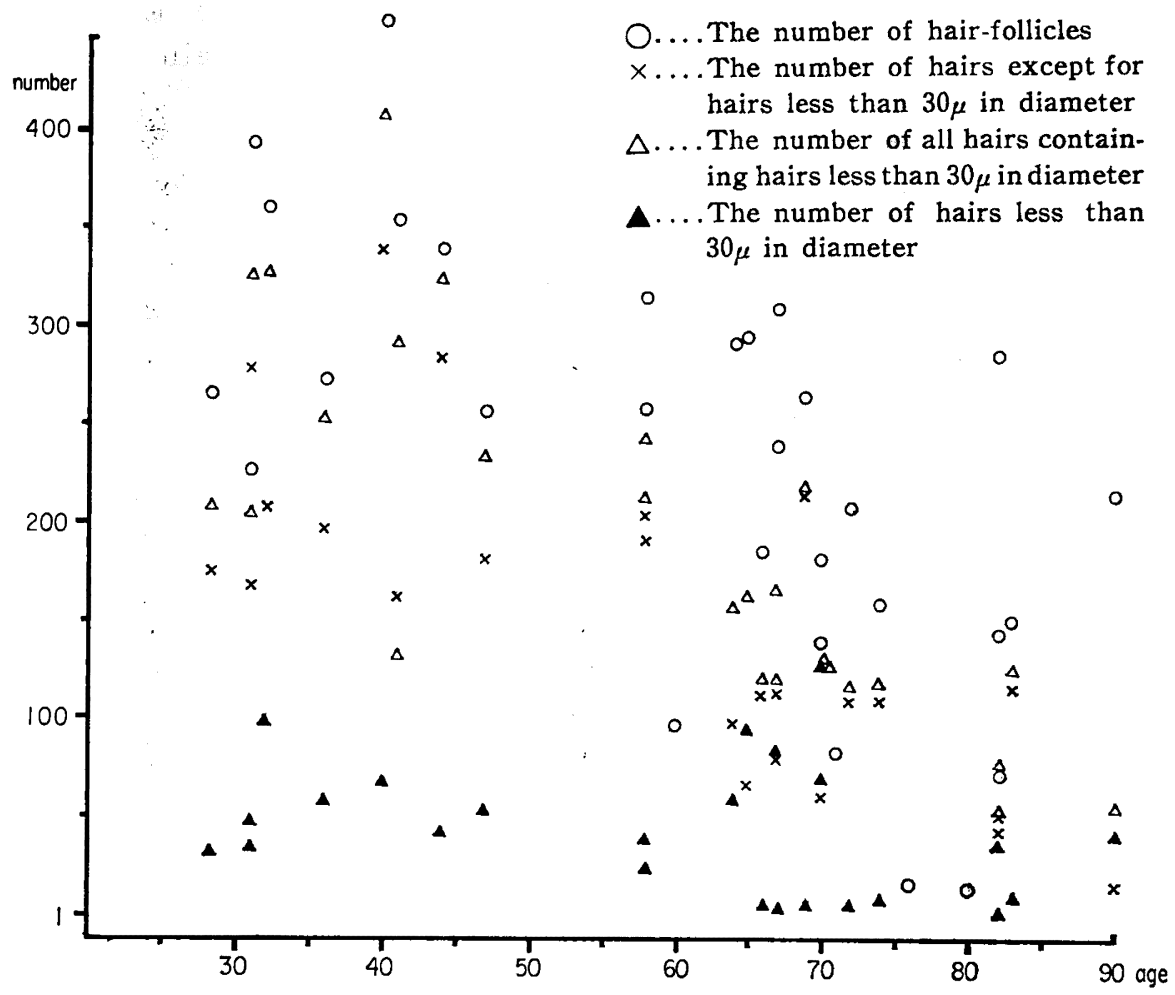

Fig. 2. The scatter gram showing the relationship among the number of all hairs, hairs more than $30 \mu$ in diameter, and hairs less than $30 \mu$ in diameter and the number of hair-follicles of those hairs.

tain the hair ratio. As shown in Table 4, this microscopic hairs ratio was $85 \%$ in the 30 -year age group; $89 \%$ in the 40 -year age group; $79 \%$ in the 50 -year age group; $56 \%$ in the 60 -year age group; $48 \%$ in the 70 -year age group; and $35 \%$ in the 80 -year age group (Fig. 3).

It is obvious from this table that the microscopic hair ratio is almost $90 \%$ in the 30 and 40 -year age groups but is decreased after age 50 and is sharply reduced in the 80 -year age group.

The number of scalp hair has been studied as early as by $\mathrm{B}$ a elz (1883) who reported the number of hairs per square centimeter in 4 adult Japanese to be 280, 298, 317 and 320, while B ir kn e r (1906) reported an average of 202 in 6 Chinese adults. B u s h makin (1928) reported the number of hairs to be from 110 to 120 in Buriates. S c h u ltz (1931) in his study which excluded individuals with evidence of baldness reported an average number per square cent- 
meter of 297 for 6 adult negroes, an average of 333 for 3 white subjects, 216 in 1 Hawaian adult and 128 in 1 adult Chinese, and suggested that the density of hair may generally be less in Mongolians than in white or negro subjects. B r u n n (1931) reported that in white subjects the number of hairs of the vertex range from 320 to 360 while that of the occiput was from 200 to 240 .

Light (1949) counted the number of hair in the crown region of 28 white and colored subjects of various ages and reported that there was an average of 131 for more or less normal scalp and that after the later part of the second decade to the early part of the third decade there is a tendency for the number of hair to decrease with aging, particularly in males. However, his scatter diagram seems to indicate that like my case it is after the age of 60 that a definite decrease is noted. There are numerous other reports on different races in which measurements were not based upon histological sections.

The report by $\mathrm{T}$ a $\mathrm{n}$ i g u c h iT. Sh ibay a ma (1935) on the number of hair per square centimeter in histological sections of the skin of the scalp from adult Japanese of various ages showed the number of hair (number of hair follicles) to be 390 in a 26 -year-old female, 467 in a 40 -year-old male,
Table 4. The proportion of hair-follicles having hairs. (hair ratio)

\begin{tabular}{|c|c|c|c|}
\hline age & $\begin{array}{l}\text { The hair } \\
\text { ratio } \\
\text { including } \\
\text { hairs less } \\
\text { than } 30 \mu \\
\text { in dia- } \\
\text { meter }(\%) \\
\end{array}$ & $\begin{array}{l}\text { The hair } \\
\text { ratio } \\
\text { except for } \\
\text { hairs less } \\
\text { than } 30 \mu \\
\text { in dia- } \\
\text { meter }(\%)\end{array}$ & $\begin{array}{l}\text { The hair } \\
\text { ratio for } \\
\text { hairs less } \\
\text { than } 30 \mu \\
\text { in dia- } \\
\text { meter }(\%)\end{array}$ \\
\hline 今 38 & 78 & 67 & 12 \\
\hline 우 31 & 90 & 74 & 16 \\
\hline 우 31 & 83 & 70 & 12 \\
\hline 今 32 & 84 & 57 & 27 \\
\hline$\hat{\delta} 36$ & 93 & 72 & 21 \\
\hline average & 85 & 66 & 18 \\
\hline 우 40 & 89 & 75 & 15 \\
\hline 今 41 & 82 & 45 & 37 \\
\hline 今 44 & 95 & 83 & 15 \\
\hline 它 47 & 91 & 71 & 21 \\
\hline average & 89 & 68 & 21 \\
\hline 우58 & 84 & 75 & 9 \\
\hline$\$ 58$ & 77 & 64 & 12 \\
\hline average & 79 & 69 & 11 \\
\hline 우60 & 0 & 0 & 0 \\
\hline$\$ 64$ & 54 & 34 & 20 \\
\hline$\$ 65$ & 55 & 23 & 32 \\
\hline 우66 & 65 & 62 & 3 \\
\hline 우 67 & 53 & 26 & 27 \\
\hline 今 67 & 50 & 48 & 2 \\
\hline 오69 & 83 & 81 & 2 \\
\hline average & 56 & 41 & 15 \\
\hline 今 70 & 89 & 0 & 89 \\
\hline 今 70 & 72 & 33 & 39 \\
\hline 우71 & 0 & 0 & 0 \\
\hline 우72 & 55 & 53 & 2 \\
\hline 우74 & 74 & 69 & 5 \\
\hline 우6 & 0 & 0 & 0 \\
\hline average & 48 & 26 & 21 \\
\hline 우 80 & 0 & 0 & 0 \\
\hline 우 82 & 72 & 70 & 2 \\
\hline 우 82 & 0 & 0 & 0 \\
\hline 今 82 & 53 & 30 & 3 \\
\hline$\$ 83$ & 83 & 77 & 6 \\
\hline$\$ 90$ & 27 & 8 & 19 \\
\hline average & 35 & 26 & 10 \\
\hline
\end{tabular}




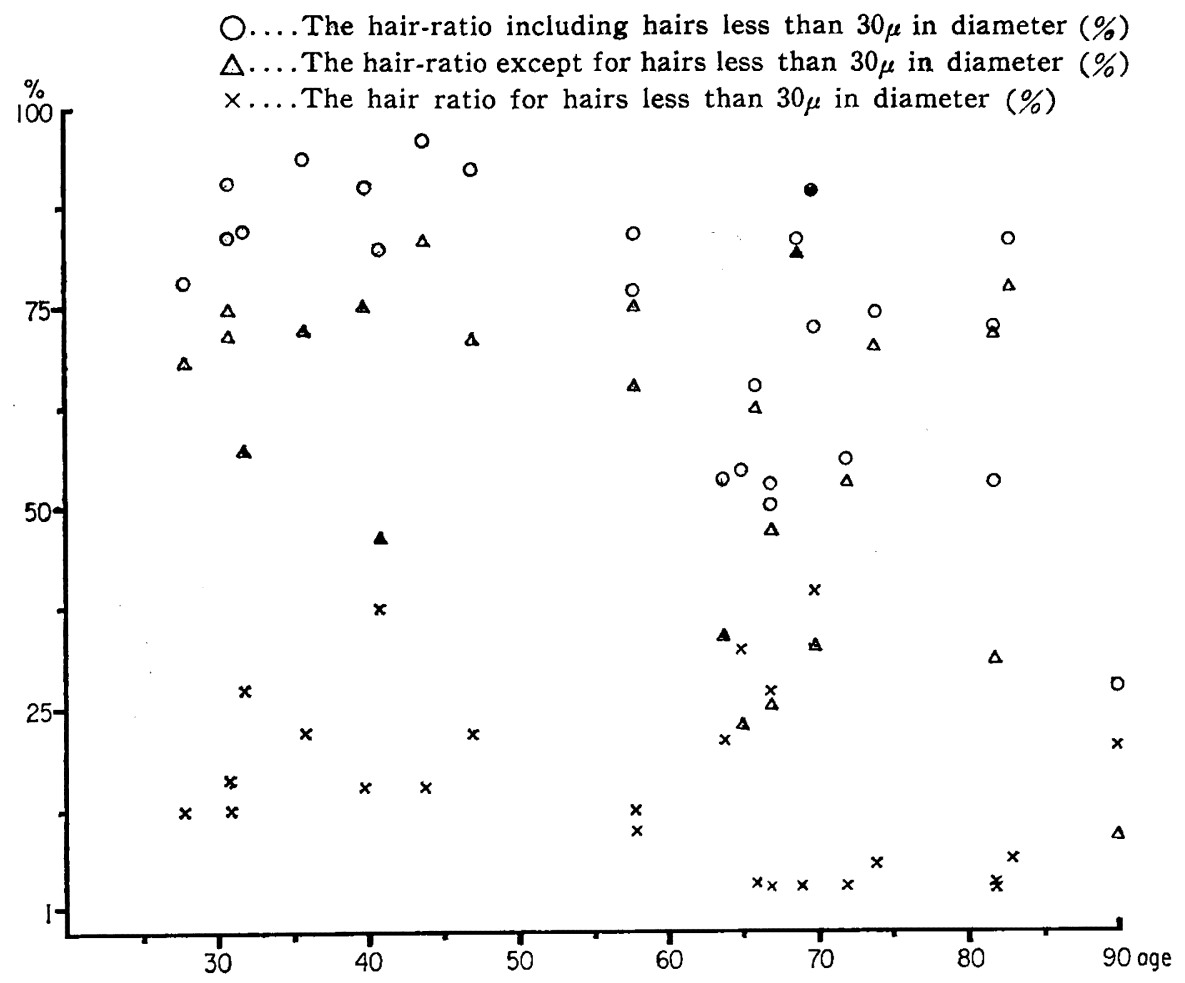

Fig. 3. The scatter gram showing the proportion of hair-follicles having hairs (hair ratio)

236 in a 58-year-old male and 527 in a 70-year-old male, all of which are greater than the average number of hair follicles for subjects of the same age group in my series. The great individual variations that can be found were also indicated. For hair, the measurements by It o-O s a d a (1955) have shown the number to be 190 in a 25year-old male, 272 in a 26 -year-old female, 196 in a 67-year-old male and 204 in a 68-year-old female which are very similar to my average values for these age groups.

As shown in Table 5, Taniguchi-H. Shiba y a ma (1935) examined 9 subjects of different races, ages 19 to 63 , and the average value of 290 per square centimeter obtained for Ainu subjects (ages 23 to 49 ) is closest to the values of the author for comparable age groups. This is an interesting finding in considering the relation between the Japanese and Ainu. Further, Ta n i g u c h i$\mathrm{K} \mathrm{u} \mathrm{rita} \mathrm{(1941)} \mathrm{have} \mathrm{made} \mathrm{measurements} \mathrm{on} \mathrm{the} \mathrm{scalp} \mathrm{of} 7$ Chinese, ages 25 to 35 , and reported an average of 439 per square centimeter 
which is considerably greater than my average value for Japanese in the 30-year age group. To study the relation between the number of hair follicles and age, $\mathrm{G}$ i a c o metti (1965) counted the number of hair follicles in 62 cases ranging from the fetal period to age 90 and found that there is a decrease after age 50 , but in my study of Japanese a marked decrease was noted with age after the age of 60 .

The state of baldness is influenced by a variety of factors, be-
Table 5. Taniguchi-Shibay a ma's report.

\begin{tabular}{|c|lc|}
\hline Age & \multicolumn{2}{|}{$\begin{array}{c}\text { The number } \\
\text { per sq. cm. }\end{array}$} \\
\cline { 1 - 3 } $19 \hat{\jmath}$ & Korean & 971 \\
$23 \hat{\delta}$ & Ainu & 635 \\
$23 \hat{\delta}$ & Ainu & 541 \\
$26 \hat{\delta}$ & Bantu & $/$ \\
$28 \hat{\delta}$ & Ainu & 739 \\
$31 \hat{\delta}$ & Ainu & 491 \\
$45 \hat{\delta}$ & German & 715 \\
$49 \hat{\delta}$ & Ainu & 504 \\
$63 \hat{\delta}$ & Finn & 671 \\
$63 \hat{\delta}$ & Bantu (Xosa) & 422 \\
\hline
\end{tabular}
sides the thickness of hair, including the density of hair distribution, color, length, etc. As a means to quantitate the state of baldness, a criterion was defined in which hairs $30 \mu$ or less in diameter were considered as being almost undetectable macroscopically and the number of such hair was counted. Atkinson, Cormita and $\mathrm{Unrau}$ (1959) have reported that the proportion of hair $27 \mu$ or less in diameter among the total number of hairs determined from the examination of 20 cases of various ages gradually increases with age until age 70 . In the present study, there was no such relation noted between hair smaller than $30 \mu$ and age (Table 3). However, the macroscopic hair ratio obtained by dividing the number of hair larger than $30 \mu$ in diameter by the total number of hair follicles was $66 \%$ in the 30 -year age group; $68 \%$ in the 40 -year age group; $69 \%$ in the 50 -year age group; $41 \%$ in the 60 -year age group; $26 \%$ in the 70-year age group; and $26 \%$ in the 80 -year age group (Table 4). That is, there already is a decrease to the $70 \%$ level from the 30 to 50-year age groups and beyond age 60, except for several cases, there is a marked decrease with aging (Fig. 3). As described later, hairs larger than $30 \mu$ are markedly reduced in diameter after the 30 -year age group and therefore, besides hairs less than $30 \mu$, there presumably are still many other hairs slightly greater than $30 \mu$ which are difficult to detect macroscopically. Furthermore, there presumably are a considerable number of small hairs or hairs being replaced that can be seen microscopically in the histological section but not seen macroscopically on the epidermis because the apex of the hair shaft has not yet reached the epidermis. When these pos- 
sibilities are taken into consideration, the proportion of hairs which can be seen on the epidermis macroscopically, that is, the actual macroscopic hair ratio may even be lower than the percentage given above and the rate of decrease with aging also may be more marked.

b) Diameter of hair

The total average diameter of hair measured at the level of the hair follicle within the dermis was $47 \mu$ for males and $52 \mu$ for females. When hair smaller than $30 \mu$ which can hardly be seen macroscopically are excluded, the numbers become $55 \mu$ for males and $68.5 \mu$ for females. The case showing the largest average value was a 31-year-old female with a value of $86 \mu$ and when hairs less than $30 \mu$ were excluded this value was $110 \mu$. As shown in Table 3 , the average value for each age group with hair less than $30 \mu$ included was $67 \mu$ for the 30-year age group, $59 \mu$ for the 40 -year age group, $52 \mu$ for the 50-year age group, $35 \mu$ for the 60 -year age group, $22 \mu$ for the 70 -year age group and $27 \mu$ for the 80 -year age group. With hair less than $30 \mu$ excluded the average values were $89 \mu$ in the 30 -year age group, $74 \mu$ in the 40 -year age group, $67 \mu$ in the 50-year age group, $50 \mu$ in the 60 -year age group, $29 \mu$ in the 70 -year age group and $32 \mu$ in the 80 -year age group. In both there is tendency of a marked decrease with aging (Fig. 4).

The diameter of hair had been measured as long ago as by B a e l z (1883) who reported values for Japanese adults of between 95 to $140 \mu$ in males and 60 to $110 \mu$ in females. Further, the diameter of hair has been reported to be $100-139 \mu$ in Chinese males by Birkner (1906), $20-160 \mu$ in Europeans by Friedenthal (1908), 92-134 $\mu$ and 105-132 $\mu$ respectively in Japanese and Koreans by $\mathrm{Ku} \mathrm{bo} \mathrm{(1913).} \mathrm{Saller} \mathrm{(1961)} \mathrm{in} \mathrm{his} \mathrm{study} \mathrm{of} \mathrm{live} \mathrm{subjects} \mathrm{re-}$ ported that there is a definite relation between the density of hair and the diameter of hair; the hair becomes more slender with increasing density. In the study of the author, such a relation could not be explored due to the small number of cases in each age group, but there evidently is a tendency for the number of both hair follicles and hairs to decrease with age after age 60 and the diameter of hair obtained for cases over age 30 also tended to decrease with aging.

A tkinson, Cormita and Unra (1959) in their study of the diameter of hair of the vertex from 20 cases ranging from ages 1 to 70 found the maximum value at ages 20 to 30 and graphically illustrated the decrease that occurred with age. These findings are consistent with the observations of the author. Goerttler (1965) 


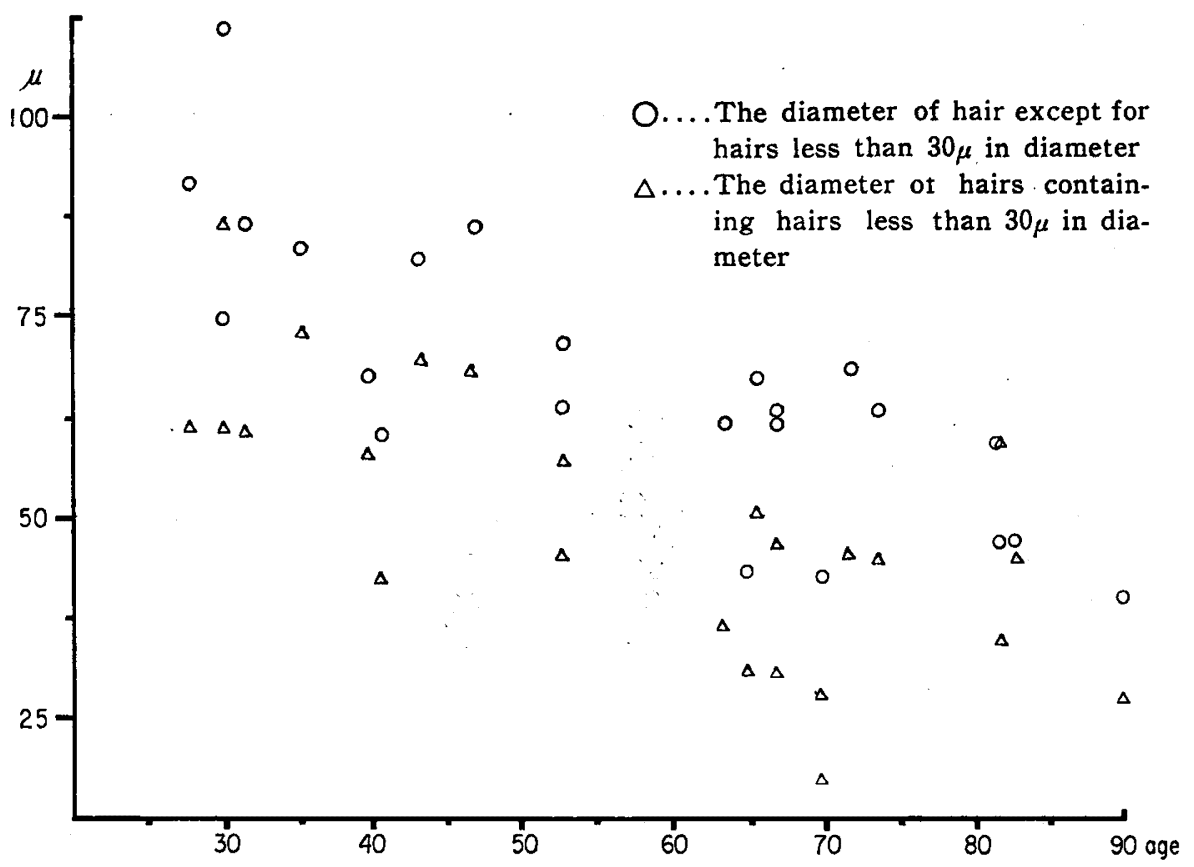

Fig. 4. The scatter gram showing the relationship between the diameter of hairs except for hairs less than $30 \mu$ in diameter and the diameter of hairs containing hairs less than $30 \mu$ in diameter.

also has noted the decrease in diameter of hair in older individuals using "splitting preparation."

$\mathrm{M}$ e yers and $\mathrm{Ham}$ ilto $\mathrm{n}$ (1951) have reported a difference by site in the growth phase of hair. In the vertex, the diameter of hair grows to $110 \mu$ in male and $147 \mu$ in female, and when a certain length is reached, there is a resting phase until the hair is shed. This hair cycle is 16 months in male and over 20 months in female. Therefore, the decrease in hair diameter with aging which I observed indicates the gradual decrease in diameter of hair each time it is replaced. One of the reasons that the diameter of hair in male is generally less than in female is possibly that due to the shorter hair cycle in male, the frequency of replacement of hair is greater resulting in smaller diameter.

\section{Summary}

1. Measurement of the thickness of the skin of the vertex in 30 Japanese adults between the ages of 28 to 90 revealed consider- 
able individual variations.

2. Although no remarkable relation was found between the thickness of the epidermis and age, the thickness of the epidermis decreases beyond age 80 .

3. The thickness of the dermis was found to decrease markedly after age 60 . Thus, the thickness of the skin likewise shows a decrease beyond this age.

4. The skin, particularly the dermis of males is thicker than in females.

5. The average number of hair follicles per square centimeter for all material examined was 229 while the average number of hairs was 159 , both of which showed marked individual differences. Comparison of the average values for each age group showed a decrease with aging in the groups over age 60 .

6. The microscopic hair ratio obtained by dividing the number of hairs by the number of hair follicles was $90 \%$ to the 40 -year age group beyond which a decrease was noted with aging. On the other hand, the macroscopic hair ratio, in which hairs that were less than $30 \mu$ in diameter and difficult to determine on gross inspection had been excluded, showed a decrease to $70 \%$ as early as in the 30 -year age group.

7. The diameter of hair showed a marked decrease with aging after the 30-year age group both with or without exclusion of hairs less than $30 \mu$ in diameter that are difficult to determine macroscopically. This presumably indicates that the diameter of hair decreases each time hair is replaced.

8. Consequently, when hairs slightly larger than $30 \mu$ which are difficult to identify macroscopically are excluded, the actual macroscopic hair ratio of the scalp is presumably less than the above percentage as early as from the 30-year age group and there is marked decrease with aging.

\section{References}

1) Atkinson, S.C., Cormita, F.E. and Unrau, A. (1959). The diameter and growth phase of hair in relation to age. British. J. Dermat. $71: 309$.

2) B a e l z, E. D. (1883). Die körperlichen Eigenschaften der Japaner. Mitt. d. Gesell. f. Natur und Völkerkunde Ostasiens. H. 32. (cited from Schultz).

3) B e r re s, H.H. (1957). Die Histologie der Alterveränderungen der menschlichen Haut. Arch. Klin. exp. Dermat. 206: 751.

4) Birkner, F. (1906). Haut and Haare bei sechs Chinesenköpfen. Arch. f. Anthropol. 3 : 142. 
5) Brunn, A. (1931) cited from Meizere, J.C.H. Integument der Mammalier. Vergl. Anat. d. Wirbeltiere. B. 1. (Bolk, L., Göp pert, E., Ka $\|$ i u s, E. and Lubosch, W., editors) Urban Schwarzenberg, Berlin.

6) Bushmakin, N. (1928). Characteristic of the brain of the Mongol race. Amer. Jour. Phys. Anthropol. $12: 228$.

7) Evans, R., Cowdry, E.V. and Nielson, P.E. (1943). Aging of human skin. Anat. Rec. 88 : 545.

8) Friedentha l, H. (1908). Das Dauerhaarkleid des Menschen. Gustav Fischer, Jenea.

9) Gia cometti, L. (1965). The anatomy of human scalp. In advancing in bio$\log y$ of skin. (M on t a $\mathbf{g}$ a, editor) Pergamont Press, Oxford, Edinburgh, New York, Paris and Frankfurt. V. $6: 97$.

10) Goerttler, K. (1965). Die menschliche Glatze in Altersformwandel der be. haarten Kopfhaut. Georg Thieme Press, Stuttgart.

11) I t o, S. and O s a d a, J. (1949). On the skin gland in Japanese. (Japanese) Yonago acta medica. $1: 131$.

12) Kodama, M. (1961). Histological studies on the age changes of human skins. (Japanese) J. Kyoto. Pref. Univ. Med. 71: 135.

13) K u bo, T. (1913). Beiträge zur physischen Anthropologie der Korkaner. Mitteilungen aus der Medizinischen Fakultät der Kaiserlichen Universitą̈ zu Tokyo. 12. B : 679 .

14) L i g h t, A.E. (1949). Histological study of human scalps exhibiting various degrees of non-specific baldness. Invest. Dermat. $13: 53$.

15) Me yers, R.J. and Hamilton, J.B. (1951). Regeneration and rate of growth of hairs in man. Ann. New York Acad. Sci. 55 : 562.

16) Parson, F.G. (1929). The thickness of the living scalp. J. Anat. $63: 427$.

17) Saller, K. (1961). Lehrbuch der Anthropolgie. 12 Lieferung.

18) Schumacher, S. (1931). Integument der Mammalier. Vergl. Anat. d. Wirebeltiere. B. 1. (Bolk, L., Göp pert, E., Kalli us, E. and L ubosch, W., editors). Urban and Schwarzenberg, Berlin.

19) Schultz, A.H. (1931). The density of hairs in primates. Human biology. 3 : 303.

20) Taniguchi, T. and Shibayama, T. (1935). Die Dichtigkeit der Körperbehaarung bei einigen Rassen. Fol. anat. jap. 13: 355.

21) Taniguchi, T. and Shibayama, H. (1935). Die Dichtigkeit der Körperbehaarung bei den Japanern. Fol. anat. jap. 13: 513 .

22) T a n i u chi, T. and Kurita, Y. (1941). Die Dichtigkeit der Körperbehaarung bei den Chinesen. Okajimas Fol. anat. jap. $20: 507$.

23) Todd, W.F. and $\mathrm{Ku}$ en $z$ el, W. (1924). The thickness of scalp. J. Anat. 58 : 231.

24) $Y$ a $z$ a w a, S. (1933). Comparative studies of human tissue in various regions in human body. (Japanese) Igaku Kenkyu. 7: 105.

25) Y o u n g, R. W. (1959). Age changes in the thickness of the scalp in white males. Human biol. $31: 74$. 